\title{
Brazilian law for scientific use of animals ${ }^{1}$
}

\author{
Lei Brasileira para o uso científico de animais
}

\author{
Ruy Garcia Marques, Marcelo Marcos Morales", Andy Petroianu ${ }^{\mathrm{III}}$ \\ ${ }^{\mathrm{I}} \mathrm{MD}, \mathrm{PhD}$, Associate Professor, Department of General Surgery, Rio de Janeiro State University, Rio de Janeiro, Brazil \\ ${ }^{\text {II }} \mathrm{MD}, \mathrm{PhD}$, Associate Professor, Department of Surgery, Rio de Janeiro Federal University, Rio de Janeiro, Brazil

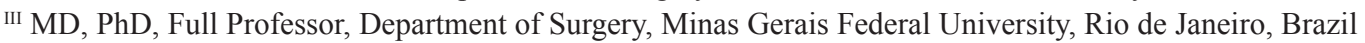

\begin{abstract}
The Brazilian scientific community claimed for a definitive systematization and for comprehensive and realistic national rules, to provide guidance and regulation, instead of sanctions, so that the question of scientific research involving animals could be better contemplated. This is beginning to occur now with Law n. ${ }^{\circ} 11.794$, sanctioned by the President of the Republic on November 8, 2008. Purpose: To describe the evolution of Brazilian regimentation for scientific use of animals and to analyze Law n. ${ }^{\circ} 11.794$. Methods: The legislation about the use of animals in teaching and in scientific research in Brazil and in Rio de Janeiro State was identified and discussed. Results: Until now, there was no updated general and systematizing rule regarding animal vivisection and experimentation for didactic or scientific purposes. The only specific law dates back to1979 and was not regimented. More recent laws equated the practice of scientific experiments to acts of abuse and mistreatment of animals, when alternative technology was available. Municipal laws that restricted the scientific practice of vivisection and experimentation with animals were created in the cities of Rio de Janeiro and Florianopolis. Conclusion: With the claim and collaboration of the scientific community, the sanction of Law n. ${ }^{\circ} 11.794$ regarding to the scientific use of animals represented an invaluable advance in spite of the presence of some points that eventually may require another type of treatment. The new Law states that it will be regimented within 180 (one-hundred-and-eighty) days, when some of these points could be better elucidated.
\end{abstract}

Key words: Experimentation; Law; Animals; Teaching; Scientific Research.

\section{RESUMO}

A comunidade científica brasileira clamava por uma norma federal abrangente e realista, mais orientadora e reguladora, e menos sancionadora, na qual a questão do uso científico dos animais pudesse ser mais bem contemplada. Isto agora começa a se materializar, com a Lei n. ${ }^{\circ}$ 11.794, sancionada pelo Presidente da República no dia 8 de novembro de 2008. Objetivo: Relatar a evolução na regulamentação brasileira sobre o uso científico de animais e analisar a Lei n. ${ }^{\circ} 11.794$. Métodos: Foi identificada e discutida a evolução na legislação existente no Brasil e em alguns municípios brasileiros acerca da utilização de animais no treinamento e na pesquisa científica, até a sanção da nova Lei. Resultados: Até agora, não existia norma geral sistematizadora atualizada referente à vivissecção e experimentação com animais, nem para fins didáticos, nem científicos. A única lei referente a esse tópico datava de 1979 e não chegou a ser regulamentada. Leis mais recentes equiparavam a prática de experimentos científicos aos atos de abuso e maus tratos de animais, na presença de tecnologia alternativa. Nos municípios do Rio de Janeiro e de Florianópolis foram criadas Leis Municipais que cerceavam a prática científica da vivissecção e da experimentação com animais. Conclusão: A partir do clamor e da colaboração da comunidade científica nacional, a sanção da Lei n. ${ }^{\circ}$ 11.794, que trata do uso científico dos animais, representou um avanço inestimável, a despeito da presença de alguns pontos que, eventualmente, merecessem outro tipo de tratamento. A nova Lei menciona que ela deverá ser regulamentada em até 180 (cento e oitenta) dias, quando alguns desses pontos poderão ser mais bem esclarecidos.

Descritores: Experimentação; Lei; Animais; Ensino; Pesquisa Científica.

${ }^{1}$ Work performed at Laboratory of Experimental Surgery - Rio de Janeiro State University, Rio de Janeiro, Brazil

\section{Introduction}

On November 8, 2008, the President of the Republic sanctioned Law n. ${ }^{\circ} 11.794,{ }^{1}$ which concerns the rearing and use of animals in teaching and research activities in Brazil.

It was indeed surprising that a nation which is training 10 thousand doctors a year, which has reached $15^{\text {th }}$ position in the international ranking of scientific publications and which, especially in recent years, has substantially increased the financial resources destined to the support of scientific and technological research, was still devoid of federal legislation regulating research activities involving laboratory animals, indispensable for technological development and for innovation in the Country.

The Project of this law was approved by Congress on May 20, 2008, after an intensive awareness-raising effort of the scientific community. The work continued in the Federal Senate and, after being evaluated by several pertinent committees, the project was approved in September. Finally, the law was sanctioned by the President on October 8 under n. ${ }^{\circ} 11.794$, and was published in the Official Record of the Union ("Diário Oficial da União") on 
October 9, 2008. The law will be regulated within a maximum of 180 (one-hundred-and-eighty) days in the Official Record.

Practically every advance in human and veterinary medicine has been obtained by means of research on animals. Many treatments and cures of important diseases still await discovery. In many situations, a pseudo-moral attitude is being used as a subterfuge in an attempt to reduce the grandiosity of the undeniable knowledge obtained with animal experimentation. Those who desire progress in world medicine are committed to work that aims to insure that scientists will have resources and freedom to continue their research. Thus, the Brazilian scientific community was demanding an encompassing and realistic federal norm, with more guidelines and regulations and with less prohibition and better contemplating the question of scientific research. This norm is now beginning to materialize, and we say it is only beginning because important steps still need to be taken for its full application.

\section{Evolution of Brazilian regimentation}

In an overall analysis, Law n. ${ }^{\circ} 11.794$ revokes Law n. ${ }^{\circ} 6.638$ of May $8,1979,{ }^{2}$ which was never regulated, and regulates section VII of $\S 1$ of art. 225 of the Federal Constitution. ${ }^{3}$ Before then, there was no updated general systematizing norm in Brazil regarding the use of animals for teaching or scientific purposes.

The Decree-Law n. ${ }^{\circ} 24.645$ of July 10, 1934 was used before then. ${ }^{4}$ This Decree, in a general manner and not yet expressly revoked, tried to regulate the transportation, hunting, work, confinement, and exposure of large animals in several types of activity. Its first article stated that "all animals existing in the Country are protected by the State". It considered as mistreatment the mutilation or wounding performed voluntarily in animals, with the exception of operations practiced in the interest of Science. Although it does not deal directly with research or vivisection, this norm considers as mistreatment: "to hit, wound or mutilate voluntarily any organ or tissue, except for castration, only for domestic animals, or other operations performed for the exclusive benefit of the animal and those required for the defense of man, or in the interest of Science" (Art. 3, section IV); "to abandon a sick, wounded, exhausted or mutilated animal and to neglect to administer to it anything that could be provided in a humanitarian manner, including veterinary care" (art 3, section V); and also "not to inflict a rapid death free of suffering to any animal whose extermination is necessary" (Art. 3, section VI).

Decree-Law n. ${ }^{\circ} 3.688$, which dealt with penal violation laws, was published in $1941 .^{5}$ In chapter VII - "Of Violations Concerning the Costume Police", the sub-item "Cruelty against animals", in art. 64, specified: "Treating animals with cruelty or submitting them to excessive work..." The penalty stipulated was simple imprisonment for a period of 10 days to one month, or a fine. Paragraph 1 of this article read: "The same penalty will be applied to whoever, for teaching or scientific purposes, performs a painful or cruel experiment on a live animal in a public place or a place exposed to the public ".

Thirty-eight years later, on May 8, 1979, Law n. ${ }^{\circ} 6.638$ started to regulate the question, establishing "norms for the didactic-scientific practice of animal vivisection". ${ }^{2}$ Fundamental principles for the use of animals in scientific research were ratified in this Law, such as: Art. 1. - Animal vivisection is permitted throughout the national territory according to the terms of this law; Art. 2 -Animal facilities and centers of experimentation and demonstrations with live animals will have to be registered with a competent Organ and be authorized to function by it; Art. 3 - Vivisection will not be permitted without the use of anesthesia at research centers or in studies not registered with a competent organ, without the supervision of a specialized technician; Art. 4 - The animal may only be submitted to the interventions recommended in the protocols of the experiments that constitute the research or the programs of surgical learning when it will receive special care during or after vivisection. However, the Law was not regulated within the period of 90 (ninety) days, as stated in art. 6. Although the Law was not regulated, according to the understanding of some jurists, this did not render it ineffective. When the Law itself fixes a deadline for its regulation, its addressees can usefully invoke its precepts and enjoy all the advantages deriving from it as long as they can forego the regulation, because the omission of the Executive Branch cannot invalidate the legal rules of the Legislative Branch. ${ }^{6,7}$ However, this law was still quite incomplete, leaving unsatisfied the desires and needs of the researchers, and had no practical effect, eventually being completely forgotten.

The Federal Constitution (1988), in its art. 225, paragraph 1, section VII, ${ }^{3}$ prohibits a practice that will submit animals to actions possibly involving "cruelty", with such a conduct subjecting the law breaker, whether a physical person or a legal entity, to penal and administrative sanctions independently of the obligation to repair the damage caused. The concept of cruelty, indefinable in an absolute manner, was not specified by the constitutional norm, with the responsibility of determining the extension of this concept according to the time and place of this conduct being left to legislator or the judge. From this perspective, especially in the scientific area, the "cruelty" implicit in a technique or an investigation is an extremely mobile concept. What is important is simply for the investigator to use the most adequate and up-to-date means and instruments to carry out an experiment in his area of activity.

In 1995, the late congressman Sergio Arouca (Rio de Janeiro state) and former President of the Oswaldo Cruz Foundation (FIOCRUZ), presented the Law Project $n .{ }^{\circ} 1.153,{ }^{8}$ regulating section VII, paragraph 1 of art. 225 of the Federal Constitution, ${ }^{3}$ establishing procedures for the scientific use of animals and proposing the abrogation of Law n. ${ }^{\circ} 6.638 / 1979 .{ }^{2}$ This Law Project represented a crucial and decisive point for the approval of Law n. ${ }^{\circ} 11.794 / 2008,{ }^{1}$ recently sanctioned by the President of the Republic of Brazil.

Law Project n. ${ }^{0}$ 3.964, of $1997,{ }^{6}$ authored by the Executive Branch, was appended to Law n. ${ }^{\circ} 1.153$. This Project regulated the rearing and use of animals for teaching and research activities, limiting them to higher education or to $2^{\text {nd }}$ degree technical establishments, and ruling that any scientific research project or activity must be supervised by a professional with higher education, a graduate or postgraduate professional in the biomedical area linked to a teaching or research entity accredited by the National Council of Animal Experimentation - CONCEA. Law Project $n .^{\circ} 3.964^{12}$ required, as a prerequisite for the accreditation of institutions, the prior constitution of an Ethics Committee for the Use of Animals (CEUA) staffed by veterinarians and biologists, faculty members ad researchers in the specific area, and a representative of a society for the protection of animals legally established in the Country. ${ }^{9}$ An ample debate followed in the 
Brazilian scientific community, led by the Brazilian Academy of Sciences (ABC), Brazilian Society for the Progress of Science (SBPC), Federation of the Societies of Experimental Biology (FeSBE), FIOCRUZ, Brazilian College of Animal Experimentation (COBEA), and Universities and Brazilian Society for the Development of Surgery Research (SOBRADPEC), among many other scientific institutions, and by the Ministries of Science and Technology, of Health, of the Environment, of Education, and of Agriculture.

Law n. ${ }^{\circ}$ 9.605, of February $12,1998,{ }^{10}$ which deals with the penal and administrative sanctions due to conducts and activities that endanger the environment, defines as an environmental crime the practice of "acts of abuse and mistreatment and wounding or mutilating wild or domestic, native or exotic animals" (Art. 32), with the penalty contemplated being imprisonment for three months to one year, and a fine. In paragraph 1 (Art.32), it considers liable to the same penalty "whoever performs a painful or cruel experiment on a live animal for scientific or teaching purposes, when alternative resources are available", with the penalty being increased from $1 / 6$ to $1 / 3$, when death of the animal occurs (paragraph 2 of art. 32).

Law Projects n. ${ }^{\circ} 1.153 / 1995^{8}$ and n. ${ }^{\circ} 3.964 / 1997^{9}$ were submitted to the Committee of Science and Technology, Communication, and Informatics (CCTCI) of the Federal Congress and were approved in the form of a Substitutive combining the two Law Projects initially presented. The Substitutive was examined and approved, with restrictions, by the Committee of Consumer, Environment and Minority Defense (CDCMAM) on June 25, 2003. ${ }^{11}$ The vote of the relater recommended the improvement of the proposals in order to incorporate international standards of respect for animals. It also recommended that CONCEA should function as a normative collegiate organ and not as an executive organ. According to the relater, the executive function should be conferred to the Brazilian Institute of the Environment and Renewable Natural Resources (IBAMA). It also understood that the possibility of decentralization should be contemplated, including the participation of the States, in order to facilitate the implementation of the law and its supervision and to create parity of representation of the scientific community and of entities and organs that, in some form, act for the defense of animals.

\section{Municipal Laws}

It is important to point out that, due to the gap existing in the federal legislation, research institutes and universities in important Brazilian cities such as Rio de Janeiro and Florianópolis remained submitted to Law Projects proposed by members of parliament of Municipal Chambers that aimed at the prohibition of scientific research with laboratory animals.

The constitutional mechanism of legislative competence about the matter is established in article 24 of the Federal Constitution, which determines the concurrent competence between the Union, the States, and the Federal District for dealing with matters regarding the protection of the environment (section VI). It is the responsibility of the Municipalities "to legislate about matters of local interest" or "to supplement the Federal and State legislation when appropriate“" (Art. 30, sections I and II). ${ }^{3}$

The Union, in its concurrent legislative competence, can publish a general norm dealing with the general criteria concerning the question. However, in the absence of a general norm, the States and Municipalities have full competence and the Public Municipal Power can establish general and specific criteria to be adopted in their territorial ambit until a federal norm is superimposed on them or is incompatible with them.

In the municipality of Rio de Janeiro, a city that concentrates an expressive number of research institutes and universities in Brazil, Decree n. ${ }^{\circ} 19.432$ of January 1, 2001, ${ }^{12}$ based on Law $n^{\circ} .9 .605$ of February 12,1998, ${ }^{10}$ which deals with the penal and administrative sanctions derived from conducts and activities that damage the environment, and in its regulating Decree $n^{\circ} .3 .179$ of September 21, 1999, ${ }^{13}$ prohibited the practice of vivisection and of experiments with animals in public municipal veterinary institutions when alternative resources are available.

In 2006, after intensive pressure on the part of the Brazilian scientific community, the Mayor of the city vetoed Law project n. ${ }^{\circ} 325 / 2005$ that prohibited vivisection and the use of animals in experimental practices provoking physical and psychological suffering for pedagogic, industrial, commercial or scientific research purposes. ${ }^{14}$

In 2007, a second project against animal experimentation was approved by the Chamber of Aldermen and again vetoed by the Mayor of the city after pressure by the Science and Technology community. Regrettably, the Chamber overthrew the veto and Law n. ${ }^{\circ} 4.731$ of January 4, 2008 was promulgated. This law does not apply to teaching and research institutions but causes difficulties for research on animals in industries, fundamental for technological development and innovation in the Country. ${ }^{15}$

Also in Florianópolis, capital city of the State of Santa Catarina and another important scientific nucleus in the Country, on December 7, 2007, Law n. ${ }^{0} 7.486$ was approved, which might create some constraints regarding investigations with animals and human health at the universities and research institutes. ${ }^{16}$ This law, " (...) disposes about the prohibition of vivisection and of the use of animals in experimental practices that will provoke physical or psychological suffering to them for pedagogic, industrial, commercial or scientific research purposes and describes other measures". The law was approved by the Municipal Chamber and was submitted to the sanction or veto of the Mayor who, by making no pronouncement, permitted the law to return to the Chamber, where it was definitively approved.

Absurd situations such as these and many others in the offing, whereby scientific activity was seriously threatened, could be avoided only with the advent of a Federal Law such as the one recently sanctioned.

\section{Discussion}

After a long period of going through the proper channels, Federal Law n. ${ }^{\circ} 11.794$ was finally approved and sanctioned by the President of the Republic. The law is available in full at http://planalto.gov.br/ccivil_03/_Ato2007-2010/2008/Lei/L11794.htm, and is also known as Arouca Law, which regulates the scientific use of animals in Brazil. ${ }^{1}$

The law permits the entire national territory to be submitted to the same law regarding the use of animals for scientific or teaching purposes. In the absence of specific laws, we used to be under the juridical interpretation of other laws that, by approximation or similarity, determined what could be considered right or wrong. Thus, this is a law that was needed even in terms of the fact that the Legislative Power could effectively legislate and 
approve it for use by the Judiciary Power, in contrast to what was previously occurring.

The text approved at the beginning of September by the Senate was sanctioned on October 8, 2008 and published in the Official Record of the Union ("Diário Oficial da União") practically in full, with no modifications of its content. Only three paragraphs of art. 11, listed below, were vetoed, which attributed competence to the Ministry of Science and Technology (MCT) to license the activities destined at animal rearing and at scientific education and research.

$\S 1$. The norms for the use and rearing of animals for scientific education and research and for the accreditation of institutions, proposed by CONCEA, will be presented to the Ministry of Science and Technology and adopted, as appropriate, by means of the available legal instruments.

$\S 2$. The supervision of the implementation of the norms for the use and rearing of animals with which this law deals, of the procedures needed for the accreditation of institutions treated in section II of the caput of art. 5 of this law, as well as the application of the sanctions stated in arts. 17 and 18 will be the responsibility of a specific organ of the Executive Power, as prescribed by the regulation.

$\S 3$. For the execution of the activities of supervision an accreditation covered by $\S 2$ of this article, the Federal Executive Power can celebrate agreements with related organs of the state, district and municipal spheres.

The vetoes only removed items repeated in the text of the law, thus preventing later juridical problems. The supervision topic is treated in another article (Art. 21) and nothing prevents the establishment of agreements with other state or municipal organs, as stated by the vetoes of $\S 3$. In the veto of $\S 1$, the normatization of the use and rearing of animals is limited to CONCEA, without the need to be submitted to the MCT for approval. Once again, the veto only intended to eliminate conflict between articles, without altering the objective of the law.

Caution should be exercised when analyzing a law since what is not stated is as important as what is determined, positively or negatively orienting the conduct of human beings in society.

According to the law, the use of animals is limited to teaching activities (which aim at the qualification of the individual) and to scientific research (which aims at the progress of human knowledge). However, practically the entire law is centered only on the second objective.

The law disciplines the educational activities with the use of animals in $\S 1$ of art. 1, by limiting the practice to higher level establishments and to those of middle level professional technical education in the biomedical area; in $\S 3$ of art. 14, which requires the obligatory use of educational methods that prevent the "unnecessary repetition of procedures" with animals; and in $\S 9$ of art. 14, which permits the execution of various traumatic procedures in the same animal during the course of a single anesthetic act, leaving it to CONCEA (section IV, art. 5) "to establish and revise the norms for the use and care of animals for teaching and research". Thus, there may be situations in which the absence of a better specification of the objectives related to teaching may be felt.

The law further states that the use of animals will be permitted in activities related to basic and applied science, to technological development, and to the production and quality control of drugs, medications, foods, immunobiological agents, instruments, and any other items tested on animals. Zootechnical practices linked to agriculture and animal husbandry are not considered to be research activities.

In section IV of art. 3 , the definition of death by humanitarian means involves the expression "minimum physical or mental suffering". There is absolutely no way to quantify this adjective in acceptable terms. In art. 14 and its numerous paragraphs, the legislators contemplate rules for the utilization of adequate sedation, analgesia or anesthesia, as well as the death of the animal under certain circumstances. Along general lines, they follow the ethical doctrine of the three "Rs" - reduction, refinement and replacement.

In Chapter II, the Law corrects a distortion existing in Law Project n. ${ }^{\circ} 3.964 / 1997,{ }^{9}$ which stated that the executive function related to research would be linked to the Ministry of the Environment and not to the Ministry of Science and Technology (MCT). It seems much more appropriate to us that this function be performed by the MCT since the animals used in research in most cases are reared for this specific purpose. In contrast, the use of wild animals is linked to research on species or on the attempts to recover species threatened with extinction and these cases are already regulated by law and linked to the Ministry of the Environment. ${ }^{17}$

The law created the National Council for the Control of Animal Experimentation (CONCEA), which would be responsible for the accreditation of institutions regarding the rearing and use of animals for scientific purposes and for the establishment of norms for the use and care of animals. Section III of art. 5 states that, in addition to accrediting institutions, CONCEA will have the attribution of monitoring and assessing the introduction of alternative techniques replacing the use of animals both for teaching and research purposes. The term "monitoring" is believed to be inappropriate, with the expression "controlling the techniques" appearing to be more adequate. It is also the responsibility of the Council to establish and revise technical norms for the installation and functioning of rearing centers, animal facilities, and experimental laboratories.

The Brazilian Society for the Progress of Science (SBPC), the Federation of Societies of Experimental Biology (FeSBE), The Brazilian Academy of Sciences (ABC), among other societies, are part of CONCEA, which will be presided by the Ministry of Science and Technology. The Council will also include representatives of the Ministries of Education, of the Environment, of Health and Agriculture, of the National Council for Scientific and Technological Development (CNPq), of the Council of University Deans of Brazil (CRUB), and of the National Federation of the Pharmaceutical Industry, and two representatives of societies for the protection of animals legally established in the Country.

Regarding the composition of CONCEA, although apparently correct, it seems to include an excessive number of participants (14 participants), a fact that would definitely increase in an excessive manner the bureaucracy regarding any process, thus hampering the productivity of the Council. If any of its members should have veto power, little progress would be made and this could be a matter of great concern. Despite the already large number of CONCEA components, in view of the orientation contained in art. 23, it would be important to include a representative of the National Council of State Foundations for the Support of Research (CONFAP). 
To be accredited by CONCEA, the institutions should first form an Ethics Committee for the Use of Animals (CEUA). Chapter III, art. 9 states that these committees will be composed of veterinarians, biologists, university professors, researchers, and a representative of a legally established society for the protection of animals and that, based on the information provided by these committees, CONCEA will set up an updated registry of the teaching and research procedures conducted on animals currently underway in the Country. Perhaps it would be more appropriate to use a representative of the society (e.g. a person from the Order of Lawyers of Brazil or from another legally constituted institution which may be concerned about the use of animals for the good of the citizens) rather than a member of societies for the protection of animals which, in most cases, would already start from the premise that something wrong is being done, a fact that would ultimately bring no benefit to the process.

Still regarding these committees (CEUAs), permitting the creation of several ones in the same institution may create cases of actions between friends or the possibility of selecting the committee according to individual interests. This may generate conflict between opposite decisions, with risky consequences. It would seem more appropriate to us that each institution should have its (unique) CEUA, with representatives of its Sectorial Centers or Units, and which would respond for the entire institution.

The law establishes penalties for institutions that do not comply with the terms defined by it, such as a warning, a fine, temporary interdiction, interruption of official financing, and definitive interdiction. These are administrative penalties that must be imposed by CONCEA, except in case of interdiction for more than 30 (thirty) days (or even definitive interdiction), when the inquisitor will be the Ministry of Science and Technology after hearing from CONCEA.

It also establishes sanctions for any persons who will execute or participate in "procedures not authorized by CONCEA", with a warning, a fine, and temporary interruption and definitive interdiction of the exercise of the activity. The penalties must be imposed on the basis of "the gravity of infraction, the damage derived from it, the aggravating or attenuating circumstances, and the antecedents of the infractor" (Art. 19).

It is interesting to note the penalty of interruption of financing on the part of official sources of credit and scientific support, since art. 23 of the law determines that CONCEA will recommend to agencies for the support of research to reject projects that are being carried out without the approval of CEUA or whose execution has been stopped by it. The law describes the hypothesis of the interruption of financing and scientific support on the part of federal agencies, but leaves to the discretion of state agencies the granting or not of support to these activities. Indeed, CONCEA is a federal organ and could not impose prohibitions on state agencies, at the risk of infringing the autonomy of federate entities.

The supervision of the research activities will be the responsibility of the "Ministries of Agriculture, Animal Husbandry, Health, Science and Technology, and the Environment in the respective areas of competence". This aspect is a source of concern since the law has established several organs of control and supervision, a fact usually known to involve inertia on the part of all agents. The regulation of the law will be useful and necessary in order to discriminate in detail the areas of performance of each organ of the Federal Administration. It is important to emphasize that the Public Ministry is also a supervising organ, a function conferred to it by the Constitution of the Republic itself and that the law cannot exclude.

The administrative penalties do not preclude those of a penal nature (Art. 20) that affect legal entities and physical persons. This is the subject of Law n. ${ }^{0} 9.605 / 98$, Environment Law, ${ }^{10}$ which "deals with the penal and administrative sanctions due to conducts and activities that endanger the environment". Thus, it is important to emphasize arts. 2 and 3 of this law, which are applicable in cases of deviant conduct and which state:

Art. 2: Whoever, in any way, practices the crimes contemplated by this law will incur in the penalties assigned to them according to his culpability, as also will the director, administrator, member of the council and of the technical organ, the auditor, the manager, the agent or representative of the legal entity, who, being aware of the criminal conduct of another, will fail to prevent its practice when they could have acted to avoid it.

Art. 3: Legal entities will be held responsible administratively, civilly and penally according to the dispositions of this Law in cases in which the infraction is committed by decision of their legal or contracted representative, or of their collegiate organ, in the interest or benefit of their entity.

Law n. ${ }^{\circ} 11.794 / 2008^{1}$ is a special law which excludes the conduct of vivisection from the practices penalized by the Environment Law, ${ }^{10}$ when authorized by CONCEA and under the conditions determined by this entity. However, there are hypotheses whereby the agent acts without the excluding norm specified by Law n. ${ }^{\circ} 11.794 / 2008$. Thus, for example, if the researcher re-utilizes the animal after the objective of the research had already been reached (a conduct prohibited by $\S 8$ of art.14), he will incur in the type contemplated by art. 32 of the Environment Law ("Practicing an act of abuse, mistreatment, wounding or mutilating of wild, domestic or domesticated native or exotic animals").

Note that Law n. ${ }^{\circ} 9.605 / 98,{ }^{10}$ which defines crimes against the environment, extends penal responsibility to all those who fail to prevent the criminal practice when they could have acted to prevent it (Art. 2. ${ }^{\circ}$ ), and also holds criminally responsible legal entities in cases "in which the breach of law is performed by decision of its legal or contracted representative or of its collegiate organ, in the interest and benefit of its entity" (Art. 3..$^{\circ}$ ).

There is much controversy about the possibility that a legal entity would be considered to be penally responsible, but the Superior Tribunal of Justice has stated its position about this topic in the special appeal n. ${ }^{\circ} 564.960$, judged on $02 / 06 / 2005$ (accessible at http://www.stj.gov.br/SCON/jurisprudencia/ doc.jsp?livre $=564960 \& \& b=A C O R \& p=$ true $\& \mathrm{t}=\& \mathrm{l}=10 \& \mathrm{i}=5)^{18}$ ruling about the possibility of the imputation of a penal conduct to these entities. On this basis, the administrative and jurisdictional organs could punish in an administrative and penal manner the natural persons and juridical entities that affront the legal precepts concerning the matter.

The law in force states that a regulation should be edited within an interval of 180 (one-hundred-and-eighty) days starting from its publication, but there is no guarantee in this respect, since the previous law was also not regulated. This regulation may possibly be one of the major obstacles regarding research with the use of animals in our Country. There is an absence of regulation on the part of the Executive Power regarding Law n. ${ }^{\circ}$ 6.638/1979 which, in synthesis, only represented a "law prototype", with only 
four articles for normatization and one for punishment, with the remaining ones being mere appendages, and which in no way satisfied the needs of the national scientific community. ${ }^{2}$

Contrary to what we may think, the lack of regulation subjects the scientific community to possible juridical interpretations of an open topic. It is easy to understand that, if CONCEA had not been created, the techniques employed for the use and care of animals could be considered as mistreatment and therefore could be punished by the juridical ordinance (Environment Law). ${ }^{10}$

Celso Antonio Bandeira de Melo, full professor of Pontifical Catholic University of São Paulo in the discipline of Administrative Law, defines regulation as a "general and usually (abstract) act of privative competence of the Chief of Executive Power, dispatched with the strict purpose of producing the uniformizing of operational dispositions necessary to the execution of the law whose application requires the action of Public Administration". 6

The legal disposition that permits the regulation of a law has the purpose of explaining it in detail and, at times, of rendering it operational (making it effective). Not all juridical norms of a normative species require regulation even when there is a legal prevision for it. In other words, a law may contain rules that need to be regulated and others that are self-executable.

As a rule, legal norms are not self-executable and do not require the action of the Executive Power to guarantee their efficacy. In some cases, the legislator is unable (or it would be improper for him) to predict the hypotheses of incidence of the juridical norm in the everyday world. This is the case! Research is dynamic and the law is static. The law should not attempt to crystallize the creative process of research, which would be the same as imposing decadence on it.

With this characteristic of uniformization of the supervising activity on the part of the Executive Power, any law can be regulated, as explained by Hely Lopes Meirelles: "Laws exist that depend on regulation for their execution, while others are self-executable. Anyone of them, however, can be regulated, the only difference being that, in the former, the regulation is a condition of their application, while in the latter this is an optional act of the Executive Power". ${ }^{7}$ It is therefore a duty, and not a prerogative, to regulate the law when necessary for its application. ${ }^{6}$ That is the reason why the Brazilian Constitution contemplates the Injunction Mandate (Art. 5. ${ }^{\circ}$, section LXXII), ${ }^{3}$ a judicial instrument that protects the constitutional rights and liberties when the lack of a regulating norm renders them unviable.

Much work remains to be done to regulate the new law and to set up and activate the committees contemplated by it. Certainly, many conducts are still destined to be regulated according to the precepts of bioethics and it will be the task of CONCEA to establish the proper limits for research on animals reared for this purpose in the laboratory.

The agencies for the support of research, as well as the managers of teaching and research institutions should be well aware of the important role they will play over the next few years in the process of changing the reality of animal experimentation in Brazil. Clear and continued policies will be necessary for the provision of financial support (modernization of animal facilities, maintenance of ethics committees etc.) and for the training of a specialized staff based on the organization of courses and events about good animal handling practices. Only with the articulated and continuous involvement of the scientific community will we indeed be able to practice the premises covered by the new Law.

We have definitely advanced a lot. The scientific use of animals is now protected by a Federal Law. Worthy, honest, conscientious and ethical professors and/or researchers needed and requested the adoption of lucid and realistic regulatory provisions that would guarantee the continuation of their teaching and research practice. However, teaching or research projects requiring the use of animals should be designed in an increasingly careful manner, with a precise evaluation of potential outcomes and taking into consideration the fundamental ethical aspects - reduction, refinement and replacement - for their execution.

\section{References}

1. Brazil. Law n. ${ }^{\circ} 11.794$, November 08, 2008.

2. Brazil. Law n. ${ }^{\circ} 6.638$, May 08, 1979.

3. Brazil. Federal Constitution (1988).

4. Brazil. Decree-Law n. ${ }^{\circ}$ 24.645, July 10, 1934.

5. Brazil. Decree-Law n. ${ }^{\circ}$ 3.688, October 03, 1941.

6. Bandeira-de-Mello CA. [Administrative Law Course. Chapter VI: Regimentation in Brazilian Law. 14 ${ }^{\text {th }}$ ed.]. São Paulo: Malheiros; 2002. p. 303-31. 7. Meirelles HL. [Administrative Law Course. Chapter IV: Administrative acts. 2nd ed.]. São Paulo: Revista dos Tribunais; 1966. p. 149-224.

8. Brazil. Federal Congress. Law Project n. ${ }^{0} 1.153$ (1995).

9. Brazil. Federal Congress. Law Project n. ${ }^{\circ} 3.964$ (1997).

10. Brazil. Law n. ${ }^{\circ}$. 9.605, February 12, 1998, art. 32.

11. Brazil. Federal Congress. Committee of Consumer, Environment and Minority Defense (CDCMAM), June 25, 2003.

12. Brazil. Municipality of Rio de Janeiro, Rio de Janeiro state. Decree n. ${ }^{\circ}$ 19.432, January 1.o, 2001.

13. Brazil. Law n. ${ }^{\circ} 9.605$, February 12, 1998, art. 32. Regulated by Decree n. ${ }^{\circ} 3.179$, September 21, 1999.

14. Brazil. Municipality of Rio de Janeiro, Rio de Janeiro state. Law Project n. ${ }^{\circ} 325$ (2005).

15. Brazil. Municipality of Rio de Janeiro, Rio de Janeiro state. Law n. ${ }^{\circ} 3.467$ (2000).

16. Brazil. Municipality of Florianópolis, Santa Catarina state. Law n. 7.486 (2007)

17. Marques RG, Miranda ML, Caetano CER, Biondo-Simões MLP. [Towards a Brazilian regimentation for use of animals in teaching and in scientific research]. Acta Cir Bras 2005; 20(3):262-7.

18. Brazil. Superior Tribunal de Justiça. Special resource n. ${ }^{0} 564.960$ (2005) (accessible at http://www.stj.gov.br/SCON/jurisprudencia/doc.jsp?livre= $564960 \& \& \mathrm{~b}=\mathrm{ACOR} \& \mathrm{p}=$ true $\& \mathrm{t}=\& \mathrm{l}=10 \& \mathrm{i}=5)$.

\section{Acknowledgment}

The authors wish to thank Alfredo de Souza Coutinho Neto for his support regarding the juridical aspects.

Corresponding author: Ruy Garcia Marques 